\title{
Foreword to special issue on geosynthetic-reinforced pile-supported embankments
}

\author{
R. J. Bathurst and J. P. Giroud
}

REFERENCE: Bathurst, R. J. and Giroud, J. P. (2020). Foreword to special issue on geosyntheticreinforced pile-supported embankments. Geosynthetics International, 27, No. 2, 110. [https://doi.org/ 10.1680/jgein.2020.27.2.110]

Geosynthetic-reinforced pile-supported (GRPS) embankments are a relatively new geotechnical technology with a strong geosynthetics component. The use of these systems to improve the performance of embankments over poor soils has expanded rapidly. Interest in these systems can be seen in the large number of technical papers on the subject that have appeared in the journal literature including Geosynthetics International. It is timely then that the Journal be able to present this special issue on GRPS embankments, which contains a collection of 15 papers on a wide range of topics related to GRPS embankments written by many of the foremost international experts.

We are delighted to have Dr Suzanne J.M. van Eekelen and Dr Jie Han as guest editors of this special issue and to have the opportunity to thank them for their many efforts in assembling this valuable collection of papers for the Journal.

Drs van Eekelen and Han first approached us with the idea of this special issue in 2017 following the very successful First International Workshop on Geosynthetic-Reinforced Pile-Supported Embankments that was held at Tongji University, Shanghai, China in June of that year. The conference was attended by experts from around the world and Drs van Eekelen and Han made the case that selected papers that were delivered at the workshop should be published in expanded form in the Journal. They also volunteered to produce a state-of-the-art paper on the theme of the special issue. Both Drs van Eekelen and Han are recognized experts on the topic and we immediately accepted their offer and appointed them as guest editors.
Table 1. Geosynthetics International special issues

\begin{tabular}{|l|c|c|c|}
\hline Subject & Year & $\begin{array}{c}\text { Volume } \\
\text { no. }\end{array}$ & $\begin{array}{c}\text { Issue } \\
\text { no. }\end{array}$ \\
\hline $\begin{array}{l}\text { Design of geomembrane } \\
\text { applications }\end{array}$ & 1995 & 2 & 6 \\
$\begin{array}{l}\text { Liquid migration control using } \\
\text { geosynthetic liner systems }\end{array}$ & 1997 & 4 & $3-4$ \\
$\begin{array}{l}\text { Geosynthetics in earthquake } \\
\text { engineering }\end{array}$ & 1998 & 5 & $1-2$ \\
$\begin{array}{l}\text { Liquid collection systems } \\
\text { Geosynthetic clay liners I }\end{array}$ & 2000 & 7 & $4-6$ \\
$\begin{array}{l}\text { Giroud lectures } \\
\text { North American Geosynthetics }\end{array} \quad 2004$ & 11 & $3-4$ \\
$\quad$ Society papers & 2005 & 12 & 1 \\
Geosynthetics applications in soil \\
and groundwater remediation \\
$\quad$ works & 2008 & 14 & 3 \\
IS KYUSHU 2007 papers & 2009 & 16 & 3 \\
Unsaturated geosynthetics & 2010 & 17 & 4 \\
Geosynthetic clay liners II & 2015 & 22 & 1 \\
\hline
\end{tabular}

Under their supervision all of the papers were subjected to rigorous peer-review by other experts. We congratulate all of the authors who contributed to this special issue and the many reviewers who critically assessed the original manuscripts.

We anticipate that this twelfth in a series of special issues of Geosynthetics International, published since 1995 (Table 1), will become an important reference for engineers and researchers interested in the design, construction and performance of GRPS embankments. 